Georgetown University Law Center

Scholarship @ GEORGETOWN LAW

2021

\title{
From Liability Shields to Democratic Theory: What We Need from Tort Theory Now
}

Heidi Li Feldman

Georgetown University Law Center, feldmanh@georgetown.edu

This paper can be downloaded free of charge from:

https://scholarship.law.georgetown.edu/facpub/2422

https://ssrn.com/abstract=3985503

Journal of Tort Law, Vol. 14, No. 2, forthcoming.

This open-access article is brought to you by the Georgetown Law Library. Posted with permission of the author. Follow this and additional works at: https://scholarship.law.georgetown.edu/facpub

Part of the Public Law and Legal Theory Commons, and the Torts Commons 
14 Journal of Tort Law, Issue 2 (2021 forthcoming)

\title{
FROM LIABILITY SHIELDS TO DEMOCRATIC THEORY: WHAT WE NEED FROM TORT THEORY NOW
}

\author{
Heidi Li Feldman*
}

\section{Introduction}

Among possible legal responses to a pandemic, quashing tort liability might seem startling. Common sense indicates that a deadly and debilitating disease would call for possible tort liability, to enable recovery for losses by those subjected to the disease because of others' carelessness while also discouraging careless conduct that could lead to preventable cases illness in the first place. Yet, when faced with SARS-CoV-2 and COVID-19, the lifethreatening disease caused by the virus, the first response of many American lawmakers was to enact, or attempt to enact, COVID-19 "liability shield"1 statutes. These laws introduced doctrine to eliminate or narrow grounds for tort claims against those who caused others to contract COVID-19.

As it turns out, the COVID-19 liability shields have an extensive pedigree in the American law of torts. In this article, I review the steady introduction of what I call "eliminative" tort doctrines, especially the wave of them dating back to the 1970s. Individually and together, these doctrines sharply reduce the grounds for personal injury claims, burden the injured's ability to prevail in permitted claims, and restrict the recovery available even when such claims succeed. Eliminative tort doctrines appear in both federal and state law and apply in a variety of factual circumstances. I maintain that existing eliminative tort doctrines facilitated the rapid promulgation of intricate, detailed COVID-19 liability shield statutes.

A fifty-year surge in eliminative doctrines is a distinctive development. It calls for explanation and interpretation. In this article, I introduce a tort theory that centers eliminative tort doctrines, rather than dismiss them as

\footnotetext{
${ }^{*}$ Corresponding author: Heidi Li Feldman, Professor of Law and (by courtesy) Associate Professor of Philosophy, Georgetown University Law Center, Washington, DC 20001, USA, E-mail: feldmanh@georgetown.edu

${ }^{1}$ The legal response to COVID-19 popularized the term "liability shield". Based on an informal search of the Access World News data base of North American news sources, 2000 and 2019, the term appeared 907 times across the publications in the database; whereas just from January 1, 2020 to September 1, 2021, it appeared 2910 times. The phrases "liability shield" or "tort liability shield" seem to date back to business-led effort to nationalize products liability law, discussed below in section 3, though in that context, their connotation was somewhat negative. See Thomas Ferraro, Consumer Groups Claim Victory, UPI(USA) (May 16, 1985), https://infoweb-newsbank-com.proxygtlaw.wrlc.org/apps/news/document-view?p=AWNB\&docref=news/15690B0EC2F91FA8). ("They argued the measure would give industry a product liability shield by imposing a greater burden of proof on consumers and by making it more difficult for them to get information from manufacturers.")
} 
aberrations or passing political fads. I title the theory "tort deflationism." It is deflationary because it treats tort law as a field that should be modest in the legal liability it creates and the extent of the liability it allows. I argue that tort deflationism is latent in the post-1960s eliminative tort doctrines and their relationship to modern American conservatism, a broad social, intellectual, and political movement that arose after World War II and continues to the present day.

I myself do not endorse tort deflationism. I have chosen to articulate it in this article in order to explore its explanatory power, evaluative force, implications for alternative tort theories, and potential significance for democratic theory and practice. Tort deflationism deserves serious attention, if for no other reason than to clarify grounds for objecting to it or to criticize its conception of the law of personal injury.

In the next three sections, I examine the COVID-19 liability shields and their predecessors so as to identify the features that any theory geared to them must illuminate. In section 5, I spell out the mid-level principles central to tort deflationism and develop a full-blown theoretical synthesis of these principles by showing their ties to the intellectual and ethical commitments of modern American conservatism. I complete the section by illustrating how tort deflationism can make sense of developments in American tort law other than the post-1960s surge in eliminative tort doctrines, using as an example the law of workplace injury. In section 6, I discuss how tort deflationism compares to other tort theories. I show that it can serve as a useful foil. Finally, in the conclusion, I suggest that my consideration of tort deflationism, its relationship to other tort theories, and its role in perpetuating disagreements about tort doctrine speak to ongoing debates about the legitimacy of law in pluralist democracies. I urge tort theorists to enter these debates and to consider their implications for tort law itself.

2 COVID-19 and tort liability shields

In late 2019 and early 2020, a new coronavirus began to sweep the world, one that, as of this writing, continues to devastate the United States. During January 2020, six Americans died of COVID-19. By the end of March 2020, 7,157 Americans had died of the disease; by the end of June, COVID-19 deaths officially numbered 18,003. ${ }^{2}$ Many more Americans had been seriously ill but had survived. By mid-March 2020, almost every state had declared a state of emergency. ${ }^{3}$ By early April, most states had issued "stay-

${ }^{2}$ Daily Updates of Totals by Week and State: Provisional Death Counts for Coronavirus Disease 2019, CDC (Nov. 5, 2021),

https:/www.cdc.gov/nchs/nvss/vsrr/covid19/index.htm.

${ }^{3}$ Rosie Perper ,Ellen Cranley \& Sarah Al-Arshani, Almost All US States Have Declared States of Emergency to Fight Coronavirus - Here's What It Means for Them, INSIDER 
at-home" orders, closing schools, daycares, and nonessential businesses, ${ }^{4}$ almost all states had limited the size of gatherings, and about half the states had mandated masks. ${ }^{5}$

By May of 2020, the business community was championing "liability shields," which would insulate business owners and operators from almost every possible kind of tort suit arising from exposure to SARS-CoV-2. ${ }^{6}$

Republicans in the United States Senate responded to this call. In July of 2020, Senate Republicans proposed the SAFE TO WORK Act (STWA), an extensive set of interlocking liability-limiting provisions that would explicitly preempt state tort law. ${ }^{7}$ States themselves also instituted COVID19 liability shields. By August 2020, roughly seven states had implemented some such measure. ${ }^{8}$ By June 2021, thirty states had adopted shields largely tracking STWA's provisions. ${ }^{9}$ In at least four states, Democratic governors signed STWA-like bills into law. ${ }^{10}$

Had STWA itself been enacted, it would have erected broad, thick, nationwide barriers to personal injury claims. According to the text of the bill, the need to federalize personal injury claims arising from COVID-19 came from the "unpredictability" created by a "patchwork of local and State rules governing liability in coronavirus-related lawsuits." 11 Whether such a

(Mar. 17, 2021, 10:34 PM), https:/www.businessinsider.com/california-washington-stateof-emergency-coronavirus-what-it-means-2020-3.

${ }^{4}$ States that Issued Lockdown and Stay-at-Home Orders in Response to the Coronavirus (COVID-19) Pandemic, 2020, BALlOTOPEDIA, https://ballotpedia.org/States that_issued lockdown and stay-at-

home_orders_in_response_to_the_coronāvirus_(COVIID-19)_pandemic, 2020 (last visited Sept. $\overline{1} 3,202 \overline{1})$.

5 State-Level Mask Requirements in Response to the Coronavirus (COVID-19) Pandemic, 2020-2021, BALLOTOPEDIA, https://ballotpedia.org/State-

level mask requirements in response to the coronavirus (COVID-

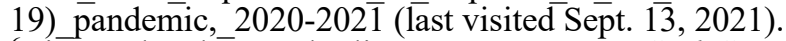

${ }^{6}$ Jim Tankersley \& Charlie Savage, Business Seek Sweeping Shield From Pandemic Liability Before They Reopen, N.Y. TIMES, (June 12, 2020),

https://www.nytimes.com/2020/04/28/business/businesses-coronavirus-liability.html; David Morgan, Businesses Seek Legal Protection for When Coronavirus Lockdowns Lift, REUTERS (Apr. 21, 2020, 3:19 AM), https:/www.reuters.com/article/us-health-coronavirususa-liability/corporate-america-seeks-legal-protection-for-when-coronavirus-lockdownslift-idUSKCN223179; Jeff Stein \& Josh Dawsey, White House Face Internal Debate Over Liability Shield for Firms Seeking Protection from Coronavirus Lawsuits, WASH. PosT (Apr. 24, 2020), https://www.washingtonpost.com/business/2020/04/24/liability-shieldwhite-house-coronavirus/.

${ }^{7}$ Safe to Work Act, S. 4317, 116th Cong. (2020).

${ }^{8}$ Elaine S. Povich, Businesses Want a Shield Against COVID-19 Lawsuits. But What About Customer Safety?, PEw RSCH. (Aug. 11, 2020), https://www.pewtrusts.org/en/research-andanalysis/blogs/stateline/2020/08/11/businesses-want-a-shield-against-covid-19-lawsuits-

but-what-about-customer-safety.

${ }_{9}^{9}$ Chris Marr, Covid-19 Shield Laws Proliferate Even as Liability Suits Do Not, BLOOMBERG L. (June 8, 2021, 2:31 AM), https://news.bloomberglaw.com/daily-laborreport/covid-19-shield-laws-proliferate-even-as-liability-suits-do-not.

${ }^{10}$ The four are Louisiana, Michigan, Nevada, and North Carolina.

${ }^{11}$ Safe to Work Act, S. 4317. 
jumble existed when STWA was proposed, now some large measure of uniformity obtains, because state COVID-19 liability shields have content very similar to one another and to STWA's major provisions.

Many of the state laws open with broadly worded announcements that no tort liability claims may arise from COVID- $19^{12}$ or none may arise so long as an alleged injurer has complied with or made a good faith effort to comply with public health guidance. ${ }^{13}$ In a couple of states, the issue of compliance is reserved to judges, to be decided as a matter of law. ${ }^{14}$ So, compliance becomes a basis for early dismissal of suits.

The statutes tend to make exceptions to their otherwise sweeping grants of immunity for situations where an injurer has acted with some degree of culpability beyond negligence, such as gross negligence, recklessness, intention, wantonness, or actual malice. But the culpability exceptions are kept trim: in some jurisdictions, compliance with public health guidance creates a presumption against finding the requisite culpability; ${ }^{15}$ in some jurisdictions, a plaintiff must establish culpability according to a clear and convincing standard rather than by a preponderance of the evidence, the lower and usual burden of proof in noncriminal cases. ${ }^{16} \mathrm{~A}$ number of state

12 ARIz. REV. STAT. $\S \S 12-515$ to 12-516(A) (LexisNexis 2020); ARK. CODE ANN. $\$ 16-120-$ 1103 (West 2021); IdAHO CodE ANN. § 6-3403(1) (West 2020); IND. CodE ANN. §34-3032-6 (West 2021); S.B. 5, 2021 Reg. Sess. (Ky. 2021); S.B. 65, 67th Leg., Reg. Sess. (Mont. 2021); N.C. Gen. Stat. AnN. § 99E-71 (West 2020); N.D. CEnT. Code § 32-48-03 (West 2021); H.B. 606, 144th Gen. Assemb. (Ohio 2021); S.C. CoDE. ANN. § 15-3-2 (2021); S.D. CODIFIED LAWs $§ 21-68-2$ (2021); TENN. CoDE ANN. 29-34-802(b) (West 2020); TeX. Civ. PRAC. \& REMEDIES CODE ANN. § 148.003 (West 2021); UTAH CODE ANN. § 78B-4-517(2) (West 2020); W. VA. Code AnN. § 55-19-4 (West 2021); WIS. STAT. ANN. § 895.476(2) (West 2021).

${ }^{13}$ Ala. Code $\S 6-5-792$ (a) to (b) (2021); H.B. 76, 32d Leg. (Alaska 2021); Fla. STAT. AnN. $\S 768.38(3)$ (c)2 (West 2021); IOWA CODE ANN. § 686D.5 (West 2020); KAN. STAT. ANN. $\S$ 60-5504 (West 2020); LA. STAT. AnN. § 9:2800.25 (2020); Mich. COMP. LAWS ANN. § 691.1455 (West 2020); Miss. CODE ANN. § 11-71-5 (West 2020); Legis. B. 39(3), 107th Leg., 1st Sess. (Neb. 2021); NeV. ReV. STAT. § 41.835(1)(b)(1)(2020); OKLA. STAT. tit. 76, $\S 111$ (B) (2021). In Montana, compliance with public health guidance may be asserted as an affirmative defense to any permitted claim arising from exposure to COVID-19. S.B. 65, 67th Leg. (Mont. 2021). In North Dakota, compliance creates a complete immunity, regardless of the degree or kind of culpability on the alleged injurer's part. Under STWA, plaintiffs had to prove that a defendant was not making "reasonable efforts" to comply with public health guidance. Safe to Work Act, S. 4317.P

${ }^{14}$ Fla. Stat. ANN. § 768.38(3)(c) (West 2021); NeV. ReV. STAT. § 41.83.

15 H.B. 76, 32d Leg. (Alaska 2021); ARIZ. REV. STAT. $\S \S 12-515$ to 12-516(A) (LexisNexis 2020); ARK. CODE ANN. § 16-120-1105 (West 2021); GA. CoDE ANN. 51-16-2(a) (West 2020); IdAho Code AnN. § 6-3403(2) (West 2020); S.B. 5, 2021 Reg. Sess. (Ky. 2021); Miss. Code AnN. § 11-71-11 (West 2020); Mo. ReV. StAT. § 533.1005 1(1) (2021); N.D. CEnT. Code $\S 32-48-02$ (2021); H.B. 606, 144th Gen. Assemb. (Ohio 2021); S.C. CodE. AnN. § 15-3-4 (2021); TenN. CodE AnN. 29-34-802(b) (West 2020); TeX. Civ. PrAC. \& REMEDIES CODE ANN. § 148.003 (West 2021); UTAH CODE ANN. § 78B-4-517(2) (West 2020); W. VA. CODE ANN. § 55-19-7 (West 2021); Wis. STAT. ANN. § 895.476(3) (West 2021); WYO. STAT. ANN. § 35-4-114(a) (West 2021). STWA permitted liability if plaintiff proved gross negligence or willful misconduct. Safe to Work Act, S. 4317.

${ }^{16}$ Ala. CODE § 6-5-793(b)(1) (2021); ARIZ. REV. STAT. § 12-515 to 12-516(A) (LexisNexis 
laws further narrow possible tort recovery by explicitly adopting a presumption of primary assumption of risk $^{17}$ based on codified waivers and warnings. ${ }^{18}$

Some states impose heightened pleading requirements on COVID-19 plaintiffs. Some laws require particularity in pleading a claim for liability arising from COVID-19. ${ }^{19}$ Some require a physician's or other scientific expert's affidavit in support of the plaintiff's initial complaint. ${ }^{20}$

Compared to other states, Alabama's liability shield law tracks STWA's handling of damages even more fully. Alabama significantly limits recoverable damages even in the tort claims permitted by the shield. A prevailing plaintiff may only win "economic compensatory damages," a category that excludes all damages for pain and suffering, mental anguish, etc. and all punitive or exemplary damages ${ }^{21}$. In wrongful death actions, Alabama bans compensatory damages entirely, allowing only punitive damages. $^{22}$

STWA itself reiterates doctrines curtailing recovery that many states had already enacted outside of their COVID-19 liability shield laws. So, STWA

2020); Fla. StAT. ANN. § 768.38(3)(c)2c (West 2021); IND. CODE ANN. § 34-30-32-7 (West 2021); Mo. REV. STAT. § 537.1005 1 (2021); S.D. CoDIFIED LAWS $\S 21-68-2$ (2021). STWA imposed the "clear and convincing standard." Safe to Work Act, S. 4317.

17 Dean v. Martz, 329 S.W.2d 371 (Ky. 1959) ("[Primary assumption of risk] is independent of negligence, as where a person participates in a sport or amusement with others or voluntarily goes or remains in a place and freely assents to conduct of another person which may involve a risk of injury not intended or which is not the result of a negligent or wrongful act.”); Kleppe v. Prawl, 313 P.2d 227 (Kan. 1957) (“[Primary]

assumption of risk arises through implied contract of assuming the risk of a known danger; the essence of it is venturousness; it implies intentional exposure to a known danger; it embraces a mental state of willingness; it pertains to the preliminary conduct of getting into a dangerous employment or relation; it means voluntarily incurring the risk of an accident, which may not occur, and which the person assuming the risk may be careful to avoid; it defeats recovery because it is a previous abandonment of the right to complain if an accident occurs."); Prescott v Ralphs Grocery Co., 265 P.2d 904 (Cal. 1954) ("The defense of [primary] assumption of risk, on the other hand, will negative liability regardless of the fact that plaintiff may have acted with due care . . . It is available when there has been a voluntary acceptance of a risk and such acceptance, whether express or implied, has been made with knowledge and appreciation of the risk ....").

18 GA. CODE ANN. § 51-16-3 (West 2021); GA. CODE ANN. § 51-16-4 (West 2020); Mo. REV. STAT. § 537.10053 (West 2021).

${ }^{19}$ Fla. Stat. AnN. § 768.38(3)(a) (West 2021); NeV. ReV. Stat. § 41.835(1)(a) (West 2020); TENN. CODE ANN. § 29-34-802(c)(1) (West 2020). STWA also called for specified particulars in a plaintiff's complaint, for example requiring the plaintiff to state "every other person or place visited by the [plaintiff] in addition to defendant and "every other person who visited the [plaintiff's] residence" and "factual basis for the belief that these persons and places were not the cause of the personal injury alleged." Safe to Work Act, S. 4317.

${ }^{20}$ Fla. StAT. AnN. § 768.38(3)(b) (West 2021); TenN. Code AnN. § 29-34-802(c)(2) (West 2020); Tex. Civ. Prac. \& Remedies Code AnN. § 148.003 (b)-(c) (West 2021). STWA also required a medical affidavit from non-treating physician. Safe to Work Act, S. 4317.

21 Ala. CoDE $\S$ 6-5-793(b)(2) (2021).

${ }^{22}$ Id. $\S 6-5-792$ (d) ("A party asserting a health emergency claim alleging wrongful death is only entitled to an award of punitive damages."). 
eliminated joint and several liability, capped any "noneconomic damages" below or at the amount of any compensatory damages, and abolished the collateral source rule. ${ }^{23}$ Furthermore, because it was proposed federal legislation, STWA had some additional distinctive features: along with an explicit preemption provision, ${ }^{24}$ STWA channeled all allowable tort suits arising from COVID-19 to federal court, by giving federal courts concurrent jurisdiction and making it easy for cases brought in state court to be removed to federal court. ${ }^{25}$

STWA was not enacted. Nevertheless, the STWA-like state laws drastically limit personal injury claims against a wide range of potential defendants. In essence, when it comes to COVID-19, these bills do away with negligence law, offering no replacement or alternative way to for COVID-19 sufferers to hold accountable those whose careless conduct demonstrably caused their infections and resulting injuries. The state COVID-19 shields also modify procedural and evidentiary requirements so that even when a suit for personal injury is allowed, the plaintiff will have a particularly tough time winning.

As I observed before, extinguishing negligence liability and severely constricting all other tort liability might seem a peculiar response to the emergence of an extremely dangerous virus. It appears considerably odder upon the realization that even before STWA was introduced and before states passed COVID-19 liability shields, state law already made it unlikely that many parties would ever face tort claims for injuries caused by COVID-19. First, workers compensation systems shield businesses from employee COVID-19 tort claims. ${ }^{26}$ Second, the widespread presence of the SARS$\mathrm{CoV}-2$ virus makes it hard for anybody to prove that a particular place was the one where they contracted their case of COVID-19. Given the realities of the contingency fee system, this causation hurdle would likely function as a de facto liability shield by discouraging plaintiffs' lawyers from ever taking cases from most COVID-19 sufferers. The unlikelihood of large numbers of personal injury claims and the even greater unlikelihood of plaintiffs winning them was reported as soon as the push for COVID-19 liability shields emerged. ${ }^{27}$ There has been no surge of claims in states where shields have

\footnotetext{
${ }^{23}$ Safe to Work Act, S. 4317.

${ }^{24} I d$.

${ }^{25} I d$.

${ }^{26}$ Most of the COVID-19 liability shield laws explicitly preserve workers compensation claims, though causation requirements under workers compensation law make these unlikely to be allowed.

${ }_{27}$ Greg Rosalsky, Should We Shield Businesses from COVID-19 Lawsuits?, WBUR (July 28, 2020), https://www.wbur.org/npr/895947722/should-we-shield-businesses-from-covid19-lawsuits; Erik Larson, et al., Businesses Fear Lawsuits from Sick Employees, Patrons After Reopening, Ins. J. (Apr. 20, 2020),

https:/www.insurancejournal.com/news/national/2020/04/20/565443.htm.
} 
not been enacted. ${ }^{28}$ Yet the clamor for COVID-19 liability shields continues. $^{29}$

\section{Predecessors to COVID-19 liability shields}

Very quickly after the initial outbreak of COVID-19, Senate Republicans were able to introduce an intricately structured set of doctrinal provisions to quash tort liability arising from COVID-19. It surely helped that STWA's drafters were not writing on a blank slate. While some of the doctrines referenced in the bills, such as primary assumption of risk, predate the twentieth century, more of the bill resembles doctrinal schemes that began appearing in the late 1970s. In this section, I provide some developments from the mid-to-late twentieth century to highlight their continuity with the COVID-19 liability shields.

\subsection{Attempted federal interventions in state products liability law}

\subsubsection{The Uniform Products Liability Act of 1979}

Starting in the 1970s, manufacturers and sellers of consumer goods sought and got federal involvement in state tort law. In 1976, the Ford administration convened a "Federal Interagency Task Force on Product Liability," later continued by the Carter administration. ${ }^{30}$ The task force laid the groundwork for a proposed Uniform Product Liability Act (UPLA), eventually promulgated by the U.S. Department of Commerce in $1979 .{ }^{31}$ UPLA justified federal involvement in state products liability law because of alleged "uncertainties" 32 it created, a harbinger of the rationale used in STWA. UPLA proffered a doctrinal scheme that would cut back on tort claims for

\footnotetext{
${ }^{28}$ Chris Marr, Covid-19 Shield Laws Proliferate Even as Liability Suits Do Not, BlOOMBERG L. (June 8, 2021, 2:31 AM), https://news.bloomberglaw.com/daily-laborreport/covid-19-shield-laws-proliferate-even-as-liability-suits-do-not.

${ }^{29}$ Chris Marr, States Prolong COVID-19 Liability Shield as Pandemic Persists, BloOMBERG L. (Apr. 20, 2021, 10:38 AM), https://news.bloomberglaw.com/daily-laborreport/states-prolong-covid-19-liability-shields-as-pandemic-persists; see David A. Lieb, Missouri Passes COVID-19 Liability Shield for Businesses, AP NEWS (Mar. 14, 2021), https://apnews.com/article/michael-brown-coronavirus-pandemic-health-government-andpolitics-ac0fcb2871569ded4ea7bd804c639d34; David A. Lieb, Arizona Governor Signs COVID-19 Liability Shield, AP NEWS (Apr. 5, 2021), https://apnews.com/article/businessarizona-health-lawsuits-legislation-fddda86f00a0b03b3e5bf6c4971440ce; Chris Marr, West Virginia Enacts COVID-19 Liability Shield, Gig Workers Law, BLOOMBERG L. (Mar. 19, 2021, 12:28 PM), https://news.bloomberglaw.com/daily-labor-report/west-virginia-enactscovid-19-liability-shield-gig-workers-law.

${ }^{30}$ Victor E. Schwartz, The Uniform Product Liability Act - A Brief Overview, 33 VAND. L. REV. 579, 580 (1980).

${ }_{31}$ Model Uniform Product Liability Act, 44 Fed. Reg. 62714 (1979).

${ }^{32} I d$. ("The Task Force found that uncertainties in the tort-litigation system were a principal cause of the product liability problem.").
} 
personal injuries caused by product sellers, partly by explicitly limiting grounds for suit and partly by making claims less valuable and so less likely to attract lawyers to represent the injured.

Among the UPLA provisions that foreshadowed later, more explicit liability shields: tying the definition of product defect to manufacturer blameworthiness (as opposed to limiting the focus to an examination of the product itself); ${ }^{33}$ narrowing claims against non-manufacturer product sellers in a distribution chain; ${ }^{34}$ presumptively deeming products not defective if they comply with administrative or legislative standards; ${ }^{35}$ requiring extensive notice of a claim to possible defendants; ${ }^{36}$ giving product sellers and their attorneys the right to recover pecuniary damages from plaintiffs who do not comply with notice requirements ${ }^{37}$ cabining the length of time for injured parties to bring claims; $;{ }^{38}$ limiting damages for pain and suffering (so-called noneconomic loss damages) and defining these as losses without market value (non-pecuniary damages); ${ }^{39}$ abrogating the collateral source rule; ${ }^{40}$ and increasing the plaintiff's burden of proof for punitive damages to the clear and convincing standard and designating the judge rather than the jury to set the amount of such damages. ${ }^{41}$

In 1980, Victor Schwartz, the chair of the panel that drafted UPLA, participated in an academic symposium where he discussed the view of tort law that guided UPLA's formulation. ${ }^{42}$ To synopsize:

- The aim of tort liability is to shift costs of some injuries from the injured to the injurer, a categorically different undertaking than supplying resources to address needs arising from injury. Liability for another person's injury should turn on a particularistic inquiry into whether the injurer is blameworthy. Causation alone is never sufficient basis for requiring the injurer to pay damages to the injured. ${ }^{43}$

- An injurer's compliance with applicable legislative or administrative standards cuts against any finding of blameworthiness. ${ }^{44}$

- Liability for personal injury should be assessed based on comparative fault with careful attention to the role of blameworthy causal conduct

${ }_{33}^{33}$ Product Liability Fairness Act of 1995, H.R. 956, 104th Cong. § 104 (1995).

${ }^{34} \mathrm{Id} . \S 105$.

${ }^{35} \mathrm{Id} . \S 108$

${ }^{36} I d . \S 109$.

${ }^{37} I d . \S 109(\mathrm{E})$.

${ }^{38} \mathrm{Id} . \S 110$.

${ }^{39} I d . \S 118$.

${ }^{40}$ Id. $\S 119$.

${ }^{41} I d . \S 120$.

${ }^{42}$ Schwartz, supra note 30.

${ }^{43}$ Id. at 584 .

${ }^{44} \mathrm{Id}$. at 588-89. 
from the injured party. ${ }^{45}$

- State legislatures should rely on uniform or model bills to ensure uniformity of tort law. ${ }^{46}$

Despite attempts, Congress never enacted a statute based on UPLA. ${ }^{47}$ But Schwartz's vision of tort law prefigured future efforts to introduce eliminative tort doctrines to state and federal law. ${ }^{48}$

\subsubsection{The Product Liability Fairness Act of 1995}

Fifteen years after UPLA, Congress passed the Product Liability Fairness Act of 1995 (PLFA). ${ }^{49}$ Though eventually vetoed by President Bill Clinton, PLFA's provisions would have effectuated eliminative tort doctrines echoing some of UPLA's and presaging some of STWA's. PLFA explicitly preempted state law; ${ }^{50}$ limited the grounds of liability for non-manufacturer product sellers to negligence and breach of express warranty; ${ }^{51}$ made a product user's intoxication or drug use a complete defense to liability if that intoxication or drug use was more than $50 \%$ responsible for the accident; ${ }^{52}$ made product misuse or alteration by the consumer a basis for reducing

${ }^{45} I d$. at $590-91$.
${ }^{46}$ Id. at 592.
${ }^{47}$ Bernard Bell, Fortieth Anniversary: The Commerce Department's Foray into Re-Writing Products Liability Law, YAle J. ON REGUl.: NotiCE AND COMMENT (Oct. 29, 2019), https://www.yalejreg.com/nc/fortieth-anniversary-the-commerce-departments-foray-intore-writing-products-liability-law/.

${ }^{48}$ Schwartz himself went on to play an individual role in these efforts. He has been prominent in the American Legislative Exchange Council, a group very active in publishing model tort doctrines, as I discuss in section 4. Schwartz went on to ALEC's "Board of Scholars," to co-chair its "Civil Justice Task Force," and, in 2003, to receive its "Private Sector Member of the Year Award." Biography: Victor Schwartz, ALEC Board of Scholars, https://www.alec.org/person/victor-schwartz/). Additionally, Schwartz is a senior member of the Shook Hardy \& Bacon law firm's "National Amicus Practice," which advertises its intervention in cases "where creative plaintiffs' lawyers seek to expand tort, product liability, and consumer law" and on "unsound litigation practices that put American businesses at risk of excessive, improper liability" and on defending "the prerogative of state legislatures to enact laws placing rational, needed constraints on liability." National Amicus Practice, SHOOK, HARDY, \& BACON, https://www.shb.com/services/practices/public-policy/national-amicus-practice. Schwartz and his partners frequently prepare and submit amicus briefs in tort litigation on behalf of the same business groups that lobbied for STWA. See id. ("The breadth and success of Shook's National Amicus Practice has made it the choice of prominent business associations including . . . U.S. Chamber of Commerce, National Association of Manufacturers . . .."). For examples, see Brief for Amicus Curiae, In Re New York City Asbestos Litigation, 216 A.D.2d 79 (N.Y.App.Div. 1995) (No. 4000/1988); Amicus Curiae Brief, Burningham v. Wright Medical Technology, Inc., 448 P.3d 1283 (Utah, 2018) (No. 20180143-SC); Amicus Curiae Brief, Liggett Group, Inc. v. Davis, 973 So.2d 467 (Fla. Dist. Ct. App. 2007) (No. SC08-541).

${ }^{49}$ Product Liability Fairness Act of 1995, H.R. 956, 104th Cong. (1995).

${ }^{50}$ Id. $\S 102$.

${ }^{51}$ Id. $\$ 103$.

${ }^{52}$ Id. $\S 104$. 
damages payable by a product seller; ${ }^{53}$ imposed a two year statute of limitations and largely limited suit to accidents caused in the first fifteen years of a product's life $;{ }^{54}$ required punitive damages to be proven by clear and convincing evidence, ${ }^{55}$ capped punitive damages $;{ }^{56}$ and eliminated joint and several liability for so-called "noneconomic loss," nonmonetary loss." 58

PLFA elaborated what became familiar justifications for federal involvement in state tort law. According to the text of the bill, these measures were necessary because "our Nation [was] overly litigious, the civil justice system is overcrowded, sluggish, and excessively costly;" 59 because damage awards [were] "excessive, unpredictable, and often arbitrary;" 60 and because state product liability law [was] inconsistent and contradictory, resulting in inequitable uncertainty. ${ }^{61}$ Overall, according to PLFA, there was "a need to restore rationality, certainty, and fairness . . . to protect against "excessive, arbitrary and uncertain damage awards. $" 62$

PLFA was vetoed. To date, there is no general, federally mandated liability shield for all products makers and sellers. But there is such a shield for one specific group of products makers and sellers.

\subsection{The Protection of Lawful Commerce in Arms Act}

In 1995, Congress enacted the Protection of Lawful Commerce in Arms Act (PLCAA), ${ }^{63}$ adding to tort law an explicit and comprehensive liability shield barring most personal injury claims against those who make and sell firearms and ammunition. PLCAA does not mince words. After two sections specifying findings and purposes, the bill has a stark, short section entitled "Prohibition on Bringing of Qualified Civil Liability Actions in Federal or State Court." 64 The first clause of the section states in its entirety, "A qualified civil liability action may not be brought in any Federal or State court." ${ }^{65}$ The second clause requires courts to dismiss any "qualified civil liability action" pending on the date of PLCAA's enactment. ${ }^{66}$ The category

\footnotetext{
${ }^{53} \mathrm{Id} . \S 105$.

${ }^{54}$ Id. $\S 106$.

${ }^{55}$ Id. $\S 108$.

${ }^{56} \mathrm{Id}$.

${ }^{57}$ Id. $\S 110$.

${ }^{58} I d . \S 101(12)$.

${ }^{59}$ Id. $\S 2(\mathrm{a})(1)$.

${ }^{60}$ Id. $\$ 2(\mathrm{a})(2)$

${ }^{61}$ Id. $\$ 2(\mathrm{a})(3)$.

${ }^{62} I d . \$ 2(\mathrm{a})(10)$.

${ }^{63} 15$ U.S.C. $\$ \S 7901-7903$.

64 15 U.S.C. $\$ 7902$.

65 15 U.S.C. \$ 7902(a).

6615 U.S.C. $\S 7902(b)$.
} 
of qualified civil liability action is broad: it includes almost all civil actions and administrative proceeding seeking any kind of relief or penalty from any firearms or ammunition manufacturer or seller, including manufacturers and sellers of component parts, if the relief sought results from criminal or unlawful misuse of the firearms, ammunition, or components thereof. ${ }^{67}$ PLCAA creates six narrow exceptions to this broad grant of immunity from tort liability. ${ }^{68}$ Though the precise reach of these exceptions is contested, ${ }^{69}$ they fall roughly into two groups. One set allows actions against manufacturers and sellers who violate certain laws aimed at preventing criminals and other legally disallowed users from obtaining guns. The other set permits gun users and bystanders to bring products liability claims for defective guns and ammunition so long as the gun was being used as intended or in a reasonably foreseeable manner and so long as the injury did not stem from a criminal discharging the weapon or using the ammunition. Notwithstanding these exceptions, PLCAA bars almost all civil claims against firearms and ammunition makers and sellers. This broad elimination of civil liability resembles the approach to COVID-19 taken in STWA and its state law counterparts.

\subsection{Eliminative tort doctrines in state law}

Many states began adopting eliminative tort doctrines in the $1980 \mathrm{~s}^{70}$ Following David Logan, we can regard eliminative tort doctrines in state law as "changes to procedure, changes to substantive law, and limits on available remedies." "71 These changes have yielded widespread limits on class actions for personal injury; requirements for medical malpractice actions ranging from binding arbitration to mandating that plaintiffs file with their judicial complaint a medical expert affidavit supporting the claim; broad statutes of repose which time bar claims based on a fix period independent of when a plaintiff discovers injury or defendant misconduct; and abolition of the collateral source rule. ${ }^{72}$

Other common eliminative doctrines in state law include: ${ }^{73}$ termination

6715 U.S.C. $\$ 7903(4)(1)(A)$.

${ }^{68} 15$ U.S.C. $\$ 7903(5)(\mathrm{A})(\mathrm{i})-(\mathrm{vi})$.

${ }^{69}$ Plaintiffs have argued, with some success, that public nuisance and consumer protection laws are sometimes applicable to the sale and marketing of firearms and ammunition, such that their violation subjects a maker or seller to personal injury claims per 15 U.S.C. $\S$

7903(5)(A)(iii).

70 Nadia Dahab, Oregon's History on Caps: The Outlook After Horton, 96 OR. L. REV. 621, 625 (2018).

${ }^{71}$ See David A. Logan, Juries, Judges, and the Politics of Tort Reform, 83 U. CINN. L. REV. 903, 907 (2015).

${ }^{72} \mathrm{Id}$. at $907-14$.

${ }^{73}$ This list is based on West Virginia's law, because West Virginia developed its eliminative tort doctrines later than other states did, aligning West Virginia law with what already 
of joint and several liability; restrictions on grounds of liability for nonmanufacturer sellers; elimination of landowner or land occupier liability for "open and obvious" dangers and for injuries to trespassers; no liability if an injury victim's own "illegal or immoral" conduct proximately caused the accident from which the claim arises; requirement that plaintiff establish punitive damages by clear and convincing evidence of defendant's actual malice toward plaintiff or conscious, reckless indifference to the health, safety, and welfare of others; caps on punitive damages; and restrictions on medical malpractice liability including caps on noneconomic damages. In various ways these doctrines resemble doctrines featured in STWA, UPLA, PFLA, and PLCAA. To some degree, this is because eliminative doctrines of all sorts have been promulgated and supported by the same group of nongovernmental organizations.

\section{Organizational drafters of eliminative tort doctrines}

Eliminative tort doctrines have consistently been promulgated or supported by the National Association of Manufacturers (NAM), the U.S. Chamber of Commerce $(\mathrm{CoC})$, and the American Legislative Exchange Council (ALEC). Their efforts merit attention for understanding the origins of the content and structure of state and federal COVID-19 liability shields and of state and federal eliminative products liability doctrines, including both those meant to cover all products sellers and those directed at specific industry. ${ }^{74}$

obtained elsewhere. See Cary Silverman \& Richard Heath, Mountain State Transformation: West Virginia's Move into the Mainstream, 121 W. VA. L. REV. 27 (2018).

${ }^{74} \mathrm{NAM}$ and $\mathrm{CoC}$ have both lobbied in favor of PLCAA, and ALEC has touted PLCAA as a model for product liability more generally. See Bill Profile: S. 397, OpEN SECRETS, https://www.opensecrets.org/federal-lobbying/bills/summary?id=s397-109 (last visited Sept. 8, 2021); and Bill Profile: H.R. 800, OPEN SECRETS, https://www.opensecrets.org/federal-lobbying/bills/summary?id=hr800-109 (last visited Sept. 8, 2021) (showing NAM's self-reports registering its lobbying related to PLCAA). See Alden Crow, Comment, Shooting Blanks: The Ineffectiveness of the Protection of Lawful Commerce in Arms Act, 59 SMU L. REV. 1813, 1821 n.73 (2006) ("America's business community weighed in strongly in favor for [PLCAA], with letters of support coming from the National Association of Manufacturers, U.S. Chamber of Commerce, National Federation of Independent Businesses."); U.S. Chamber of Commerce Supports $S$. 659, INST. FOR LEGIS. ACTION (Aug. 4, 2003), https://www.nraila.org/articles/20030804/uschamber-of-commerce-supports-s-6 (quoting a letter from $\mathrm{CoC}$ executive vice-president for government affairs stating that "[t]he U.S. Chamber is greatly concerned about the growing trend of litigation being filed against entire legal industries with the goal of either raising government revenue or achieving policy goals outside the constraints of the political process. The Protection of Lawful Commerce in Arms Act would help curtail this abusive situation"). When testifying to Congress in favor of PLCAA, lobbyists for the gun industry and gun users specifically cited NAM and CoC support for the bill. Lawrence G. Keane, Testimony during House Hearing at 109th Congress (Mar. 15, 2005) (transcript available at https://www.govinfo.gov/content/pkg/CHRG-109hhrg20015/html/CHRG-

109hhrg20015.htm). See also Amy Kjose Anderson, Should State Legislators Embrace Bernie Sanders'Policy, ALEC (Feb. 9, 2016), https://www.alec.org/article/should-state- 
In April 2020, NAM urged Congress to "prevent[] the creative use of state [personal injury law] claims" 75 in a press release entitled "Manufacturers Fight COVID-19 But Face Legal Obstacles." ${ }^{76} \mathrm{NaM}$ exhorted Congress to create "Pandemic Liability Policy Protections." 77 Eventually, when Republican Senators introduced STWA, NAM's general counsel announced, "The SAFE TO WORK Act mirrors the liability recommendations proposed by manufacturers as part of our 'American Renewal Action Plan' in April (emphasis added)." 78

Also in the spring of 2020, both CoC and its Institute for Legal Reform (ILR) began pressing for federal action to curtail COVID-19 related tort claims. In April, ILR held a virtual event called "COVID-19 Federal Liability Issues and Solutions." 79 Subsequently, CoC wrote to Congress, listing a panoply of possible COVID-19 related legal claims it wanted Congress to extinguish. The letter dedicated an entire section to "Exposure Liability." There, CoC pushed for a Congressionally enacted "safe harbor" from negligence suits against companies so long as they were following "CDC or state/local guidelines" and they had not committed "gross negligence, recklessness, or willful misconduct." ${ }^{81} \mathrm{CoC}$ also advocated "channeling . . . claims into federal court," a device eventually incorporated into STWA. In July, CoC included specifics of their proposal for shielding companies from COVID-19 personal injury claims in a sweeping set of asks addressed to President Donald Trump, Speaker of the House Nancy Pelosi, and Senate Majority Leader McConnell. ${ }^{82}$

While NAM and CoC concentrated on the federal government, ALEC published a model state bill that, without mentioning COVID-19 explicitly,

legislators-embrace-bernie-sanders-policy/ (characterizing PLCAA as "a commonsense lawsuit reform protecting gun manufacturers from scheming theories of liability" and urging that the same immunity from suit in PLCAA should be extended to all products manufacturers).

${ }^{75}$ NAM Newsroom, Manufacturers Fight COVID-19 but Face Legal Obstacles, NAT'L Ass'N OF MFRS. (Apr. 22, 2020, 9:06 AM), https://www.nam.org/manufacturers-fightcovid-19-but-face-legal-obstacles-8088/?stream=policy-legal.

${ }^{76} I d$.

${ }_{77} I d$.

${ }^{78}$ Manufacturers on SAFE TO WORK Act, NAT'L ASS'N OF MFRS. (July 28, 2020, 4:51 PM), https://www.nam.org/manufacturers-on-safe-to-work-act-9995/?stream=series-pressreleases.

${ }^{79}$ ILR Briefly Live Event: COVID-19 Federal Liability Issues and Solutions, U.S. CHAMBER INST. FOR LEGAL REFORM, https://instituteforlegalreform.com/event/ilr-brieflylive-event-covid-19-federal-liability-issues-and-solutions/ (last visited Sept. 8, 2021).

${ }^{80}$ Memorandum from Suzanne Clark, President of U.S. Chamber of Commerce to Members of U.S. Chamber of Commerce on Implementing a National Return to Work Plan, (Apr. 13, 2020), (on file with U.S. Chamber of Commerce).

${ }^{81} I d$.

${ }^{82}$ Letter from Thomas J. Donahue, CEO of U.S. Chamber of Commerce, to Donald Trump, President, Mitch McConnell, Senate Majority Leader, and Nancy Pelosi, House Speaker (July 16, 2020) (on file with U.S. Chamber of Commerce). 
would nevertheless severely limit COVID-19 related personal injury claims. If enacted, state laws based on the "Liability Protection for Employers in a Declared Disaster or Public Emergency Act" (Liability Protection Model Act) would: ${ }^{83}$

- $\quad$ eliminate most tort claims against every possible defendant. Covered defendants included "any natural person, partnership, corporation, limited liability company, company, trust, estate, for-profit or nonprofit association, or any other business entity" and "the state, a political subdivision, emergency management agency, or other agency of the state including but not limited to universities." 84

- make compliance with federal agency regulations, state and local statutes and regulations, and gubernatorial and presidential executive orders a bar to all civil liability. ${ }^{85}$

- $\quad$ in the absence of regulations, statutes, or executive orders, restrict civil liability to reckless or willful misconduct. ${ }^{86}$

- $\quad$ prohibit courts from recognizing implied private rights of action from statutes, regulations, executive orders, or guidance issued in response to a disaster or emergency. ${ }^{87}$

The Liability Protection Model Act generalizes the details and architecture of STWA, expanding them to cover all official emergencies and disasters. It also draws on ALEC's work on eliminative tort doctrines in other contexts, especially in products liability law.

In 1995, ALEC published its Model Products Liability Act (MPLA). MPLA defines and categorizes product defects as UPLA did, ${ }^{88}$ tying them to manufacturer blameworthiness. Again, like UPLA, it limits products liability claims against product sellers other than manufacturers. ${ }^{89}$ But the more major resemblances between UPLA and MPLA are found in further ALEC model bills that MPLA incorporates by reference. Because the incorporated model bills are not specific to personal injuries caused by products, the latest version of MPLA includes much of ALEC's blueprint for the entire law of personal injury, not just products liability.

The Regulatory Compliance Congruity With Liability Act provides three

${ }^{83}$ Liability Protection for Employers in a Declared Disaster or Public Emergency Act, ALEC, https://www.alec.org/model-policy/liability-protection-for-employers-in-a-declareddisaster-or-public-emergency-act/ (last visited Sept. 8, 2021).

${ }^{84} I d$. (quoting from $\S 1(2)$ ).

${ }^{85} I d$. (quoting from $\S 2(1)$ ).

${ }^{86} I d$. (quoting from $\left.\S 2(3)\right)$.

${ }^{87} I d$. (quoting from $\$ 2(4)$ ).

${ }^{88}$ Product Liability Act, ALEC (amended Jan. 1, 2012), https://www.alec.org/modelpolicy/product-liability-act/, (defining defect in terms of what makes a product "unreasonably dangerous," breaking out defects into manufacturing, design, and failure to warn; including deviation from express warranty as possible unreasonably dangerous defect in $\S 4$ ).

${ }^{89} \mathrm{Id}$. (providing rules of liability for product sellers in $\S 8$ ). 
options for making compliance with administrative and legislative standards, order, and approvals suffice to defeat personal injury claims. ${ }^{90}$ The Ten Year Statute of Repose Act limits the time period in which a personal injury claim can be brought against a product seller or a service provider. ${ }^{91}$ The Assumption of Risk Act reestablishes primary of assumption of risk as a complete defense to a tort claim. ${ }^{92}$ The Transparency in Lawsuits Protection Act prevents courts from recognizing implied private causes of action arising from legislation. ${ }^{93}$

Apart from what the MPLA incorporates by reference, ALEC has published numerous other bills fleshing out its vision for tort law. The Comparative Fault Act bars recovery if a fact-finder concludes the plaintiff's fault exceeds that of injurers, including those not before the court. ${ }^{94}$ The Punitive Damages Standards Act is extremely detailed. Among other measures, it requires punitive damages only on a showing of "actual malice," a level of culpability to be proved by "clear and convincing evidence"; disallows plaintiff from pleading a specific amount in punitive damages; excludes evidence of the defendant's financial condition or net worth; and sets a ceiling on punitive damages. ${ }^{95}$ The Noneconomic Damages Awards Act caps damages for pain and suffering and other categories of loss which the act deems "subjective" and "nonpecuniary." 96 The Truth in Damages Act abrogates the collateral source rule. ${ }^{97}$ The Fair Share Act eliminates joint and several liability in all tort cases except for when the plaintiff can prove conscious and deliberate concert of action to commit an intentional tort. ${ }^{98}$ The Rational Use of a Product Act permits product liability only if the injury arises from reasonable and foreseeable misuse of a product rather than simply

${ }^{90}$ Regulatory Compliance Congruity with Liability Act, ALEC (amended Jan. 28, 2013), https://www.alec.org/model-policy/regulatory-compliance-congruity-with-liability-act/ (providing three options under the model act when a service provider or manufacturer complies with the law: no liability, rebuttable presumption of no liability, or no punitive damages).

${ }^{91}$ Ten-Year Statute of Repose Act, ALEC (amended June 23, 2017), https:/www.alec.org/model-policy/ten-year-statute-of-repose-act/.

${ }^{2}$ Assumption of Risk Act, ALEC (amended Jan. 28, 2013), https:/www.alec.org/modelpolicy/assumption-of-risk-act/ (stating that defendant is not liable if an injured person knew of and appreciated the risk posed by the defendant and voluntarily exposed herself to resulting danger that caused her injury or damage).

${ }^{93}$ Transparency in Lawsuits Protection Act, ALEC (amended Jan. 28, 2013)

https:/www.alec.org/model-policy/transparency-in-lawsuits-protection-act/.

${ }_{94}$ Comparative Fault Act, ALEC (amended Jan. 28, 2013), https://www.alec.org/modelpolicy/comparative-fault-act/.

95 Punitive Damages Standards Act, ALEC (amended Jan. 9, 2014), https://www.alec.org/model-policy/punitive-damages-standards-act/.

96 Noneconomic Damage Awards Act, ALEC (amended Jan. 9, 2014), https://www.alec.org/model-policy/noneconomic-damage-awards-act/.

97 Truth in Damages Act, ALEC (amended Aug. 1, 2007), https://www.alec.org/modelpolicy/truth-in-damages-act/.

${ }_{98}$ Fair Share Act, ALEC (amended Jan. 28, 2013), https://www.alec.org/model-policy/fairshare-act/. 
a foreseeable misuse. Even when a plaintiff reasonably uses a product in an unintended way, this constitutes misuse for purposes of considering the plaintiff's comparative fault and leads to a reduction in damages to the extent the plaintiff's use of the product caused the injury. ${ }^{99}$ The Actual Harms Act restricts damage claims to those that produce documented economic loss. ${ }^{100}$ The Anchors Away Act prohibits plaintiffs from specifying to juries any particular amount of damages, or range of amounts, for pain and suffering and other nonpecuniary losses. ${ }^{101}$

ALEC disseminates its model tort doctrine widely, and research indicates that ALEC model bills regularly influence state legislatures. 102 Unsurprisingly, then, all the aforementioned ALEC model bills have counterparts in many states' COVID-19 liability shields as well as in their more general tort doctrine.

5 The theory of tort deflationism

For almost fifty years, eliminative doctrines have been proliferating in both federal and state law. We need to consider how tort theory can make sense of them, their interrelationship with each other, and their connection to the larger body of law governing personal injury. In this section, I formulate an initial version of a tort theory sensitive to this project, a theory I call "tort deflationism." I begin by extrapolating from the doctrines reviewed in prior sections a set of mid-level principles. Such principles sit between doctrine and a full-blown theory.

\subsection{Mid-level principles}

Drawing from the eliminative tort doctrines surveyed in section 3, we can develop some mid-level principles that lend coherence to them:

- Except under limited, delineated conditions, the state should not hold injurers legally liable to those they injure.

- When injurer-to-injured legal accountability is permitted or required,

\footnotetext{
${ }^{99}$ Rational Use of A Product Act, ALEC (amended Jan. 28, 2013), https:/www.alec.org/model-policy/rational-use-of-a-product-act/.

${ }_{100}$ Actual Harms Act, ALEC (May 6, 2016), https://www.alec.org/model-policy/actualharms-act/.

${ }_{101}$ Amendments to Anchors Away Act, ALEC (Jan. 8, 2021), https:/www.alec.org/modelpolicy/anchors-away-act/.

102 Molly Jackman, ALEC's Influence over Lawmaking in State Legislatures, BROOKINGS (Dec. 6, 2013), https://www.brookings.edu/articles/alecs-influence-over-lawmaking-instate-legislatures/ ("ALEC model bills are, word-for-word, introduced in . . . state legislatures at a non-trivial rate. [T] hey have a good chance - better than most legislation of being enacted into law.").
} 
there should be limits on the amounts and kinds of damages available to the injured.

- Exceptions to the presumption against injurer-to-injured legal accountability should be based on the culpability of the injurer; generally, a showing of negligence does not suffice and proving a more knowing, even malicious, state of mind is necessary.

- The extent or severity of harm an activity risks does not ground exceptions to the presumption against injurer-to-injured accountability.

- Tort liability should serve the interests of producers, sellers, and service providers and by so doing serve the interests of the entire community.

- Legislatively enacted tort law is often superior to judicially created tort law.

- Uniform tort law across the states is desirable.

- Injurers are not accountable to injury victims who knowingly and voluntarily assume risk of injury.

- When a criminal causes injury no other party is legally accountable to the injury victim.

- The only losses from personal injury that the law can reliably ascertain are those that can be quantified in terms of market value.

- When tort claims are allowed, they should be tightly circumscribed: threshold issues of fact should be decided by judges; to establish liability plaintiffs should have to meet standards of proof higher than the preponderance of the evidence; to survive dismissal, complaints should be highly particular and be accompanied by verification of the validity of the allegations by an expert witness.

A full-blown tort theory concerned with eliminative doctrines should organize and interrelate these mid-level principles with reference to more general intellectual and ethical commitments. In extant academic tort theories, such commitments have, to date, come from a range of sources including Kantian moral philosophy, virtue ethics, neo-classical economics, feminist theory, critical race theory, classical Lockean political theory, liberal egalitarianism, American legal realism, and philosophical pragmatism. Tort deflationism, by contrast, draws on a body of broad intellectual and ethical commitments, coming from another, and very different, source.

\subsection{Modern American conservatism}

The mid-twentieth century emergence of eliminative tort doctrine coincides with the advent of a larger intellectual, social, and political movement: 
modern American conservatism. There is an extensive literature about this movement, with contributions from proponents, critics, journalists, and scholars. ${ }^{103}$ For present purposes, I supply the following précis of its definitive ideas and themes, giving prominence to those particularly pertinent to tort deflationism.

Modern American conservatism fuses ideas from libertarianism, Chicago-School free-market economics, and Christian evangelicalism. This synthesis approves only a small range for government action. Government may act to maintain order, stability, and certain kinds of hierarchy, but only if it does not encroach upon the prerogatives of appropriate churches (white evangelical Christian ones and those with sufficiently comparable tenets and practices), acceptable families (heterosexual, two-parent, patriarchal), and the market (capitalist). In part, this restrictive view about the acceptable scope for government action rests on beliefs about the inherent authority of these other institutions and the clash between their proper jurisdiction and state power. The view also rests on a belief about the incompetence of government. Government is too removed, too big, too clumsy for tasks other than keeping the peace. When government does properly maintain order and stability, individuals and nongovernmental organizations can attend to all the other tasks government might attempt but is likely to botch. In short, it is not only that the demands of liberty that require limited government action; so too do the demands of well-being. For the most part, individuals and nongovernmental institutions left to their own devices enjoy freedom from illegitimate government supervision and ultimately do a better job of improving social welfare.

\subsection{From mid-level principles to more full-blown tort theory}

With this admittedly abbreviated synopsis of modern American conservatism in mind, we can start to order and synthesize the mid-level principles. The most foundational principle for full-blown tort deflationism is the presumption against legal accountability from an injurer to those caused injury (injurer-to-injured legal accountability). This presumption broadly

\footnotetext{
${ }^{103}$ My own precis of modern American conservatism draws from many sources including:

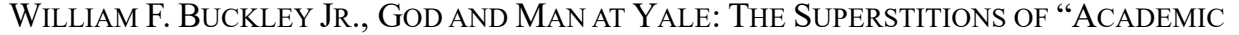
FrEEDOM” (Regnery Gateway 2021) (1951); FrANCES FITZGERALD, THE EVANGELICALS: The Struggle to Shape America (2017); Barry Goldwater, THe Conscience OF A Conservative (1st ed.1960); Russell KirK, The Conservative Mind: From Burke to Eliot (Regnery Gateway 2016) (1953); GEORGE H. NASH, THE CONSERVATIVE INTELLECTUAL MOVEMENT IN AMERICA SINCE 1945 (Intercollegiate Studies Institute 2014) (1976); DONALD T. CRITCHLOW, PHYLlis SCHLAFLY AND GRASSROOTS CONSERVATISM: A Woman's Crusade (2008); Peter Steinfels, The NeOconservatives: The Origins of A Movement (2013); Benjamin C. Waterhouse, Lobbying America: The Politics of BuSINESS FROM NiXON TO NAFTA (2014).
} 
safeguards against overreaching governmental efforts to address injurious activity and its consequences. While some governmental efforts in this area are warranted, neither the simple fact of injury or suffering nor their seriousness suggests that government can legitimately or competently do anything about either injury or suffering. Hence, the basic presumption against injurer-to-injured legal accountability.

Where government action may be needed is to handle injury-causing activity that threatens order, stability, and appropriate hierarchy. In this situation, injurer-to-injured legal accountability may be warranted. When people set out to injure others or flagrantly ignore the risks of doing so, their conduct poses a palpable threat to order. Thus, it makes prima facie sense to make exceptions to the presumption against injurer-to-injured legal accountability in cases of intentional, willful, wanton, or reckless conduct that causes others injury. But caution against government overreach and ineptitude counsels against making this accountability too easily sought or won. Keeping damage awards low, allowing damages only in some categories, and refusing damages for any losses that cannot be priced via the market makes it less attractive for individuals to trigger government action in the form of a lawsuit resulting in a legally enforceable judgement against a defendant. So too does giving injurers repeated opportunities to avoid legal accountability and to reduce its costs. Hence, the use of procedure to limit claims and recovery.

Though tort deflationism thus anticipates some injurer-to-injured legal accountability, it also expects that it should be as cabined as possible, including by legislative codification. Statutory authorizations of personal injury claims can be written narrowly, thereby discouraging judicial expansion of legal accountability. Additionally, legislative codification can impose or foster uniformity in legal accountability across jurisdictions, which in turn improves conditions for a national market, expanding opportunity for providers of goods and services.

Whether legislative or judicial, government action should be a last resort. For example, it is better to rely on the market itself to minimize personal injury caused by producers, sellers, and service providers. Market competition can foster safety and even post-injury compensation. Government action to ensure competition may be necessary, but after that the market itself will curb excessively unsafe practices from producers, sellers, and service providers and, if enough consumers prefer it, will inspire them to offer post-injury recompense. To the extent the market does not adequately weed out reckless or willful conduct from these producers, sellers, and providers, culpability-based exceptions to the general presumption against injurer-to-injured legal accountability come into play.

The choice of whether to encounter risk of personal injury should remain 
with the individual. For the most part, individuals can protect themselves from risk by choosing to refrain from activities that subject them to it. Furthermore, when a person knowingly and voluntarily subjects herself to the risk of a particular kind of injury, her choice overrides the legal significance of almost anybody else's causal role in bringing about that injury. The only exception is criminal conduct that causes injury. Criminal conduct overrides the significance of any non-criminal's actions, including the injury victim's. This is because criminal action that inflicts personal injury seriously threatens order, licensing legal consequences for the criminal. These consequences can include legal accountability from the criminal to one he has personally injured.

To summarize: tort deflationism integrates commitments from modern American conservatism with the mid-level principles that span eliminative tort doctrines. This theoretical synthesis situates the presumption against injurer-to-injured legal liability in the context of overall limitations on government action, while also delineating the relatively confined circumstances under which the presumption can be overcome, and more permissive tort doctrines allowed.

\subsection{The reach of tort deflationism: the law of workplace injury}

A tort theory should have reach. This means it should be able to illuminate large areas of law, including those that seemingly run counter to the theory. While I developed tort deflationism to account for the post-1960s wave of eliminative tort doctrines, it can illuminate other developments in the law of personal injury. To demonstrate, I consider the law of workplace injury, which, early in the twentieth century, saw a turn toward more permissive tort doctrines, and then, in the first half of the twentieth century saw the rise of workers compensation programs as the exclusive venue for settling legal accountability for workplace injuries. Tort deflationism, I argue, makes sense of both developments.

Too many workers injured too badly unsettles business operations and strains the ability of non-state institutions to provide for injured workers and their dependents. If the workplace becomes too perilous, labor may exit or organize to demand safer conditions, interfering with production and challenging owners' and managers' authority over the work environment. When conditions like these arise, tort deflationism can, without contradiction or incoherence, explain the demise of eliminative tort doctrines. It can account for judicial reworking of doctrines that had completely barred employers' tort liability throughout the nineteenth century, functioning as a liability shield. When the high incidence of workplace injury created disorder, instability, and resistance to traditional hierarchy, the law shifted 
just as tort deflationism would expect it to.

Just as tort doctrine governing workplace injury started to become more permissive, state governments began to replace tort liability altogether with workers compensation schemes. Compared to litigation, these made it easy for injured workers to file claims and gain monetary relief. ${ }^{104}$ One might think this would pose a puzzle for tort deflationism, though as it actually turns out, tort deflationism is quite useful for understanding the advent of workers compensation programs with the features generally adopted in the United States.

When the demands of order necessitate some kind of employer-to-worker legal accountability, tort deflationism can account for a switch from adjudication to administrative programs as long as the latter minimize cost and burden to employers compared to the former. In an administrative system, payments can be kept low. They need not make the injured whole so long as they are sufficient to head off unrest, prevent workers exiting the labor market, and discouraging collective action by labor. ${ }^{105}$ By using schedules rather than personalized damage awards, an administrate program makes employer costs more amenable to actuarial prediction, lowering the costs of liability insurance and further minimizing burdens on employers. To ensure that an administrative system does not lead to further employer-to-injuredemployee legal accountability, the system should be legislatively codified and administratively conducted without opportunity for judicial expansion. Today's workers' compensation systems have all these features. They are legislatively codified, agency administered, exclusive channels for employerto-employee legal accountability. ${ }^{106}$ They replace tort liability with a more

104 This is the so-called Grand Bargain struck by workers compensation systems. See PRICE V. Fishback \& Shawn Everett Kantor, A Prelude to the Welfare State: The ORIGINS OF WORKERS' COMPENSATION 120-147 (2000) (surveying the trend toward eliminating tort suits as an alternative to workers compensation); NAT'L BUREAU OF ECON. RsCH., The Regulated ECONOMY: A HistoriCAl APPROACH TO POLITICAL ECONOMY 265 (Claudia Goldin \& Gary D. Libecap eds., 1994) (explaining that NAM and state business organizations saw workers comp as a way to "stem the tide of more frequent and larger jury awards to injured workers," as state legislatures began to take away the common law defenses from employers); Robert Asher, The 1911 Wisconsin Workmen's Compensation Law: A Study in Conservative Labor Reform, 57 THE WIS. MAG. OF Hist., no.2, Winter 1973-1974, at 123-40, https://www.jstor.org/stable/4634868 (discussing that employers were open to workers compensation insurance programs if the worker chose between the workers compensation scheme or being sued in tort; employers accepted workers compensation schemes because of a tendency in the courts towards more liberal verdicts to injured laborers circa 1905; employers feared that courts would eventually take away the typical employer common-law defenses).

${ }^{105}$ Insistence on limited payments to injured workers continues today. See The Critical Need to Reform Workers' Compensation, Am. Pub. Health Ass'N (Nov. 7, 2017), https:/www.apha.org/policies-and-advocacy/public-health-policy-statements/policydatabase/2018/01/18/the-critical-need-to-reform-workers-compensation (discussing state legislatures' ongoing resistance to increased payment amounts and describing arguments against extending coverage to from traumatic, acute injuries to chronic disease).

${ }^{106}$ Debates over whether to adopt workers compensation programs explicitly centered on 
restricted and predictable form of liability, one that excludes so-called noneconomic damages and schedules so-called economic ones. This is precisely the sort of administrative substitution for tort law tort deflationism can account for.

\section{Tort deflationism and other tort theories}

Having laid out a preliminary version of tort deflationism, I now consider ways it contrasts with some other tort theories. These are not the only contrasts that could be drawn, and I do not even attempt to discuss all the tort theories from which tort deflationism differs. The comparisons made here show how considering tort deflationism can throw other theories into relief. This can reveal insufficiently defended assumptions in other theories. It can also show how theories that look dissimilar in some ways look more alike when considered from the vantage point of tort deflationism. It can prompt broader questions about what makes one tort theory superior to another.

Despite differences among extant tort theories, many of them depend on moral ideals explicitly meant to apply universally. ${ }^{107}$ The relevant moral ideals may be deontological or consequentialist, concerned with human dignity or human welfare, but regardless, it is the very universality of the ideal that gives it force in accounting for how any given country's tort law is and how it should be. The ideals that inform tort deflationism are different: more contextualized because anchored explicitly to the American situation. Modern American conservatism does not attempt a universal moral theory. Its prescriptions depend on contingent features of American history and culture, such as secular government, certain kinds of churches, an established capitalist market, and so forth. Modern American conservatism considers what is right and good for this kind of place, one with these features. Tort deflationism inherits this contextual sensibility: it is a theory of American tort law, not of tort law across nation-states. In fact, tort deflationism may have an advantage over more universalizing tort theories. Its explanatory and interpretive power might only extend to American tort law, but its sensitivity to the American context may allow it to make better sense of prominent

these issues. See Price V. Fishback \& Shawn Everett Kantor, The Adoption of Workers' Compensation in the United States, 1900-1930, 41 J. OF L. \& ECON. 305 (1998). The exclusivity feature was key to employer acceptance of workers compensation. FISHBACK \& KANTOR, supra note 104, at 99-100, 105-07.

${ }_{107}$ Some examples of scholars who have written from universalist moral principles in aid of transnational tort theory: PETER CANE, THE ANATOMY OF TORT LAW (1997) (characterizing tort law through a universal ethical principle of personal responsibility); JOHN GARDINER, FROM PERSONAL LIFE TO PRIVATE LAW (2018) (presenting tort law as part of a more general, universalized theory of moral duty); Mark Geistfeld, Hidden in Plain Sight: The Normative Source of Modern Tort Law, 91 N.Y.U. L. REV. 1517 (2016) (asserting a universal talionic normative basis for tort law). 
features of American tort law than more universalized theories can. If this is so, why should we abandon tort deflationism for more universalized tort theories? Even if we reject tort deflationism, it should push us to face and answer questions of whether and how much universalism in tort theory matters.

Tort deflationism can also problematize theories more explicitly rooted in ideals arguably embedded in American culture and history. For example, some critical tort theories start from ideals of equality that arguably have or should have force and meaning within the American context. Then, by showing where tort law disguises or perpetuates certain kinds of inequality, critical tort theory supplies a basis to change tort doctrine. Feminist tort theory, for example, sometimes proceeds by demonstrating that seemingly neutral tort doctrines both rest on and contribute to the ongoing subordination of women. ${ }^{108}$ But the defender of existing doctrines might rely on tort deflationism to take the sting from this critique. First, the defender might argue, it is not true that American ideals of equality extend to gender. Second, even if they do, it is not the place of law, including tort law, to realize ideals of gender equality. The government is neither inherently empowered nor competent to implement ideals like equality between men and women. Gender-hierarchy is not a relevant reason to change tort law.

This sketch of debate between feminist tort theory and tort deflationism illustrates the capacity of tort deflationism to explain and even to justify tort law's role in perpetuating arrangements that critical theorists present as antithetical to distinctly American ideals. Tort deflationism may provide a basis for disagreeing about the content of the asserted ideals. More damaging to the critical theoretical enterprise, however, tort deflationism can account for the irrelevance of the critical ideal to tort doctrine, without ever contesting the nature of the ideal itself. The tort deflationist can applaud the ideal, but still maintain that it does not justify a larger role for injurer-to-injured legal accountability. Even if we reject tort deflationism, considering it highlights a general question for the enterprise of tort theory: does it matter, and how much does it matter, if a tort theory puts tort law beyond the reach of critical perspectives rooted in the American perspective?

So far, I have juxtaposed tort deflationism with tort theories that assign substantive moral ambitions--whether universal or more culturally embedded - to tort law. Now, I examine how tort deflationism can challenge theories that purport to make sense of tort law without imparting to it any particular moral ends. Theories like this makes sense of tort law with

\footnotetext{
${ }^{108}$ Martha Chamallas and Jennifer Wriggins, leaders in critical tort theory, repeatedly and powerfully deploy this tactic to show how existing tort law perpetuates both gender-based and race-based hierarchies. See Martha Chamallas \& JenNifER B. Wriggins, The MEASURE OF INJURY: RACE, GENDER, AND TORT LAW (2010).
} 
reference to how it generates, through iterated processes of trial and appeal, principles of interpersonal obligation and ascertains how to apply these in contested cases. ${ }^{109}$ Theories like this present tort law as primarily procedural.

Consider civil recourse theory, which rejects the idea of any substantive moral end as having a necessary place in tort law. ${ }^{110}$ Civil recourse theory conceives of tort law as a "system of relational directives, rights and duties, and powers and liabilities," 111 arrived at by the processes of common law adjudication. The content of these directives, rights, duties, powers, and liabilities is not preordained by anything, including the government. The system is "not fundamentally about a state or a sovereign commanding people to behave the way it wants them behave so that it can achieve its purposes."112 It is merely "a formalized version of informal, everyday practices of people holding themselves and each other accountable." 113

Civil recourse theory presents tort law as merely an apparatus for giving people the chance to develop obligations and the rest, with their content to be generated through the operation of the apparatus. That government hosts the apparatus does not mean the government is dictating the substantive content of what gets generated.

For now, grant this distinction between process and substance. Tort deflationism will still object to tort law as construed by civil recourse theory. Tort deflationism's reservations about government overreach apply as much to a government-sponsored system for yielding obligations as they do to more direct government decrees outlining what we are obligated to do for each other. Even if tort law is ex ante neutral as to the content of such obligations, there is no guarantee that the output of the processes of tort law will restrict injurer-to-injured accountability to what is necessary to maintaining order. An open-ended process for the development of legally enforceable interpersonal obligations might end up dictating obligations that go well beyond this purpose, obligations that intrude upon the prerogatives of individuals and nongovernmental organizations to determine what we owe each other when.

Putting tort deflationism alongside civil recourse theory showcases a problem for all procedural tort theories: how can these theories defend

${ }^{109}$ Christina Carmody Tilley provides a rich account of how this aspect of existing tort law builds community among people with a range of ethical views. Tilley makes sense of tort law with reference to this sociological function. See Cristina C. Tilley, Tort Law Inside Out, 126 YALE L.J. 1320 (2017).

${ }^{110}$ According to its leading proponents, civil recourse theory relegates purposes such as corrective justice, fairness, deterrence, efficiency, compensation, equality, and social harmony to the legislature, thereby removing them from what is distinctive to tort law proper. John C. P. GOLDBERG \& BENJAMIN C. ZIPURSKY, RECOGNIZING WRONGS 357-58

(2020).

111 Id.

${ }^{112} I d$. at 362 .

${ }^{113}$ Id. at 61 . 
outputs that clash with moral or critical commitments others refuse to relinquish?

Some have grappled with the intractability of disagreement about the proper ends for tort law not by emphasizing its procedural aspect but by suggesting a more compartmentalized approach to tort law's subject matter. According to pluralists, tort theories animated by different goals and concerns might be suitable for categorically different circumstances of personal injury. ${ }^{114}$ The pluralist observes that variety in tort doctrine arises from systematic dissimilarities in the type of parties to a tort claim, the complexity of evidence, and differences in the nature and extent of typical losses. Such variety militates against single-purpose or single-principle tort theories being able to make sense of all the doctrines of American tort law. Better to pursue a more disjunctive approach, taking seriously the possibility that we will end up with a subdivided law of torts, with different divisions made sense of in different ways. Whether or not this pluralist strategy can efface the conflicts between other theories of tort law, it will not be able to accommodate tort deflationism. Tort deflationism presumptively disallows injured-to-injurer legal accountability in all settings. Variation in applicable tort law turns on and can be explained by variation in what is necessary for maintaining order, not on a group of diverse, further goals. Thus, tort deflationism highlights a limit on pluralist reconciliations of tort theory: the appearance of different doctrines for different classes of injury need not signal different ends for different parts of tort law.

In this section, I have concentrated on some of the ways tort deflationism challenges the content, argumentative strategy, and methodological tenets of other tort theories and raises issues of how to show one tort theory's superiority to another. In the final section of this article, I argue that consideration of tort deflationism alongside other tort theories should motivate a reexamination of the questions with which tort theories of all kinds should concern themselves.

\section{Conclusion}

When it comes to theorizing about tort law, there is something of a feedback mechanism from theory to practice. Judges, legislators, lawyers, and commentators embed theory in the substantive law itself by referencing it in opinions, legislative materials, briefs, and treatises. Lawyers appeal to tort theory to support their side in controversial matters; judges and legislators use tort theory to settle debates one way or the other. Tort deflationism gives practitioners, lawmakers, and commentators a resource from which to

${ }^{114}$ See Christopher J. Robinette, Can There Be a Unified Theory of Torts? A Pluralist Suggestion from History and Doctrine, 43 BRANDEIS L.J. 369, 413-14. 
establish eliminative tort doctrines other theories reject and to dispense with permissive tort doctrines other theories support. Not only can it keep argument over these doctrines alive, but if it is incorporated, explicitly or implicitly, into practical legal materials themselves, tort deflationism becomes part of the law, propelling future doctrinal development in accord with its tenets. At the same time, tort deflationism is unlikely to convince everyone. We can expect other theories to continue to feed back into practice too. With rival theories fueling competing doctrines, we can see that tort theorizing is unlikely to settle disagreements. By deepening the grounds for clashing viewpoints, tort theorizing very probably renders disputes over substantive tort law all the more intractable. The prospect of such systematic, thoroughgoing, entrenched disagreement raises a theoretical issue not usually associated with the overall enterprise of tort theory: the legitimacy of law in twenty-first century pluralist democracy. I want to close this article by suggesting that tort theory should regard this problem as more central to understanding tort law and thus to tort theory itself.

The twenty-first century has seen a division in democratic theory over the significance of disagreement among members of pluralistic democratic nation-states. On one side are theorists who base the legitimacy of law in such states on demonstrating some sort of reasoned consensus, available through processes of dialogic persuasion. ${ }^{115}$ There are variations concerning the specifics of the requisite consensus: it might be hypothetical, realized only under idealized conditions, and extend to basic principles that govern or regulate how laws are made, rather than to the particulars of the laws themselves. But for all in this camp, law's legitimacy depends essentially on the reasoned consensus of the governed. Another school of democratic theory regards deep, even tragic, disagreement over law and politics as the defining feature of a truly pluralist democracies: in these polities, we cannot arrive at reasoned consensus, no matter how much idealization is allowed and no matter how basic the consensus is permitted to be. ${ }^{116}$ Virtually every significant legal arrangement is arrived at or maintained by exerting power over members of the polity who are not, and will not be persuaded to be, party to any sort of meaningful consensus about the arrangement itself. For those in this school, the problem of legitimacy cannot be solved through deliberative consensus; it must be solved, if it can be, by reconciling hegemony with democracy. What is needed is an account of how power can legitimately be exercised to determine legal arrangements.

115 This school of democratic theory is grounded in the work of John Rawls and Jürgen Habermas.

${ }^{116}$ Leading thinkers in this school include Chantal Mouffe, Bonnie Honig, and William Connolly. My discussion here follows Chantal Mouffe, Agonistics: Thinking the World Politically. See Chantal Mouffe, Agonistics: Thinking the World Politically (2013). 
At this juncture, I am not concerned with which school of democratic theory is ultimately correct. Rather, I canvass the debate within democratic theory to alert tort theorists. I have used tort deflationism to show that we should anticipate ongoing, pervasive disagreements over which tort doctrines are permissible, desirable, or forbidden. Moreover, the feedback between tort theory and tort practice makes these disagreements more abiding, not less. I believe that tort theory should recognize how contested tort law is.

What is the significance of ineradicable and serious fights over the substantive tort doctrines to have? Do these struggles undo the legitimacy of tort law in our pluralist democracy? Does it matter if settled doctrine rests on hegemony rather than consensus? Can tort law show how some forms of hegemony are either conducive to or at least not destructive of law's legitimacy? Or does tort law illustrate the necessity of ridding law of the influence of power or at least of certain kinds of power? If tort theory seeks to make sense of tort law, it must grapple with questions like these.

Acknowledgments: First and foremost, I thank Ariana Lazzaroni and Eric Dolce for their dedicated and excellent research assistance. This article could not have been completed without their fine work. For extensive and useful conversation about the piece, I thank Eileen John. I thank Robin West for her careful, thoughtful feedback on an earlier version. Throughout this article I cite other tort scholars' work as appropriate. But because the article addresses tort theory generally, many scholars' writings inform the discussion. I will inevitably fail to name all those I should, but in addition to the authors cited in this article, I want to express my appreciation to the following for their published work related to tort theory, works that have aided my own effort here: Ken Abraham, Anita Bernstein, Greg Keating, Virginia Nolan, Michael Rustad, Emily Sherwin, Edmund Ursin, and G. Edward White. 